Expl Agric. (1996), volume 32. pp. 67-78

Printedin (ireat Britain

Copypght (C) 1996 Cambridge I nizersity Press

\title{
JA\#1655
}

\section{SIMULATING ROOT SYSTEM DEVELOPMENT OF SHORT-DURATION PIGEONPEA}

\author{
By GAYATRI DEVI, O. ITO†, R. MATSUNAGA†, S. TOBITA+, \\ T. P. RAO, N. VIDYALAKSHMI and K. K. L.EE \\ International Crops Research Institute for the Semi-Arid Tropics (ICKIS.AT), \\ Patancheru, Andhra Pradesh 5)2.324. India
}

(Accepted 1.June 199.5)

\begin{abstract}
SIMMARY
langth and weight of pigeonpea roots were measured weekly in dillerent soil layers and compared with estimates obtainced from a root simulation model using daily climatic datta, soil phỵsico-chemical propẹtrtices and dry matter allocation to roots. Daily moisture comtent and temperature at diflerent soil depths were well simulated using sub-routines from the (:I:Rl:SMaize model. Daty allocation of dry matter to roots was calculated fiom lengistic liunctions fitted to the growth data for shoots and roots. Although root length and weight tonded to lo. underestimated by the model, regressions between measured and simulated ront growth were highly significant so that the model could, with a few modifications, be used to predict rout system development.
\end{abstract}

\section{INTRODUG:"ION}

Crop growth models are now used to predict many agronomic processes but are still in the early stages of development for many crops. Only limited information is as yet available about crop growth for pigeonpea, a grain legume: important to resource-poor farmers of the semi-arid tropics and known to be deep rooting (Arihara et al., 1991) which is a key factor for the exploitation of soil resources.

The root growth routines in whole crop models are not comparable in complexity and sensitivity to the shoot growth routines and cannot be used for accurate prediction. Existing root models (Hoogenboom and Huck, 1986; Huck and Hillel, 1983) are complex and require many inputs as the architecture of the root system is itself influenced by many factors such as soil, environment and the various interactions between the roots and shoots. Model selection therefore needs to be guided by the main areas of interest of the study.

Both static and dynamic stress factors in the soil affect root growth. Static soil stress factors such as aluminium toxicity ( $\Lambda$ dams and Moore, 1983), calcium deficiency (Ritchey et al., 1982) and presence of coarse fragments, and dynamic soil stress factors like soil strength (Gerard et al., 1982), acration (Asady and

Present addresses: †Japan International Research Center for Agricultural Sciences, 1-2 Ohwashi, Tsukuba, Ibaraki 305, Japan; †Japan International Research Center for Agricultural Sciences, Okinawa Branch, Japan. 


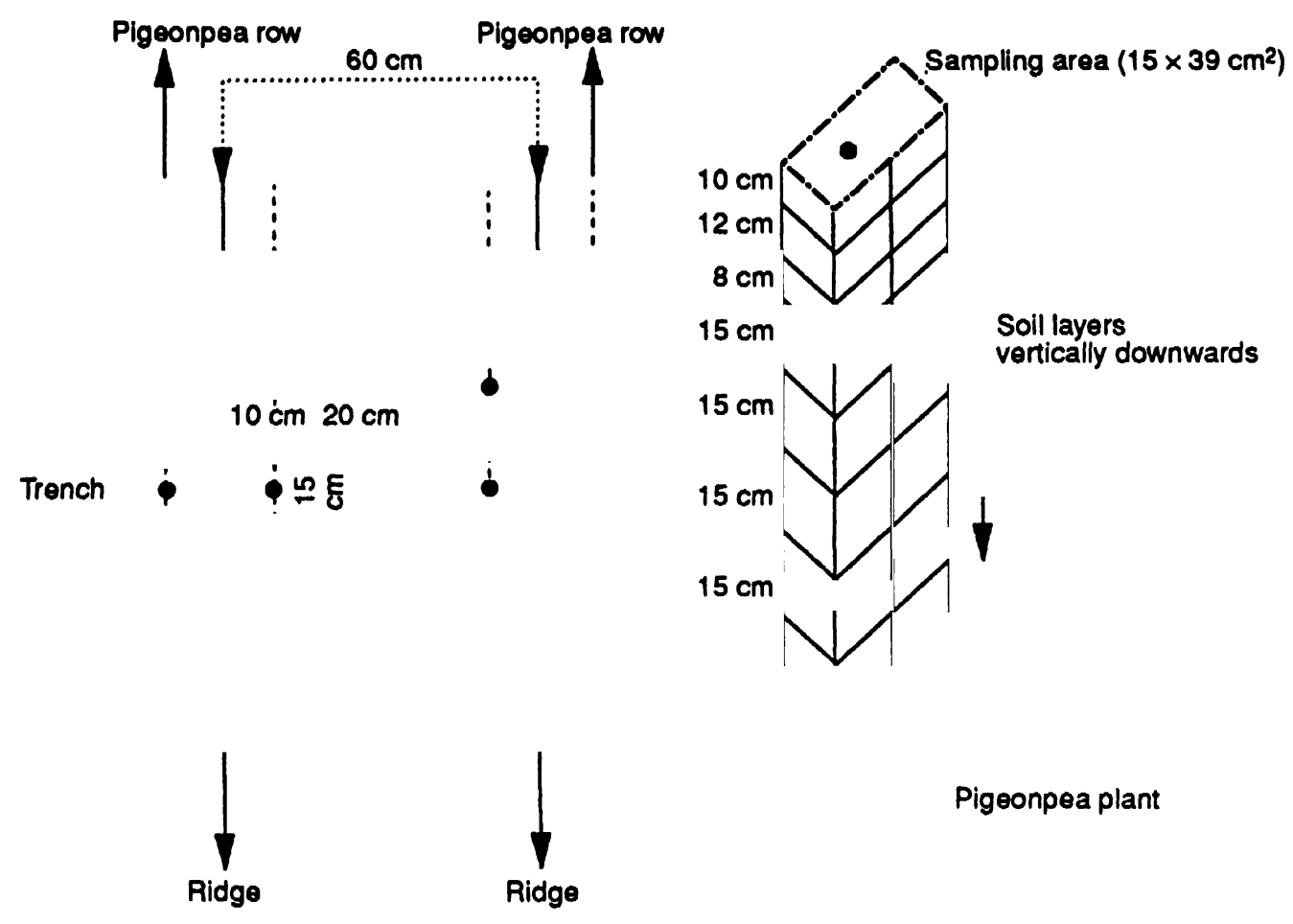

Fig. 1. Schematic diagram showing the row arrangement of short-duration pigeonpea, the direction of the trench and the location of soil blocks for monolith sampling on the trench wall.

Smucker, 1989; Drew, 1983) and temperature (Gregory, 1986) are the major external factors governing root development. These studies show that root growth is sensitive to soil aeration, may be limited by low soil temperature and has an approximately linear relation with soil strength. Soil water content and temperature change considerably during the cropping season and their effect on the root system should be estimated frequently if seasonal change in root growth and death is to be observed.

The results of the simulation of root growth and distribution of a short duration pigeonpea in an Alfisol are presented here and problems associated with application of an existing model to pigeonpea are discussed.

\section{MATERIALS AND METHODS}

\section{Crop agronomy and site description}

A short-duration pigeonpea cultivar (Cajanus cajan (L.) Millsp. cv. ICPL 87) was sown on 20 June 1992 at the International Crops Research Institute for the Semi-Arid Tropics (ICRISAT), Patancheru, India $\left(18^{\circ} \mathrm{N}, 78^{\circ} \mathrm{E}\right)$. The total rainfall during June to October in 1992 was about $670 \mathrm{~mm}$ and the maximum and minimum temperatures were between $34-30^{\circ} \mathrm{C}$ and $24-22^{\circ} \mathrm{C}$, respectively.

Diammonium phosphate was applied at $100 \mathrm{~kg} \mathrm{ha}^{-1}$ before sowing. Ridges were prepared $60 \mathrm{~cm}$ apart and the seeds sown in rows on either side of each ridge with $15 \mathrm{~cm}$ between plants in a row and $20 \mathrm{~cm}$ between rows (Fig. 1). The area of 
the entire experiment was $12 \times 18 \mathrm{~m}$ with three replications, and the size of each plot was $12 \times 6 \mathrm{~m}$. Plants were thinned to one plant per hill 14 days after sowing (DAS). A sprinkler irrigation was given six times during the growing season and the amount of water applied was recorded. The pigeonpea was harvested at 110 DAS.

\section{Sampling and measurements}

Roots were collected by soil-root monolith sampling (Heeraman and Juma, 1993). A trench was dug manually in each plot at weekly intervals (a total of 15 times during a whole growing season). The soil blocks were sampled layer by layer from one side of the trench wall (Fig. 1). The soil was separated into 0-10, $10-22,22-30,30-45,45-60,60-75$ and $75-90 \mathrm{~cm}$ layers which were then washed with tap water to obtain crude root fractions consisting of roots and other plant debris. Crude roots were then separated and kept at $-20^{\circ} \mathrm{C}$ until their measurements were recorded. Root length was measured by a root length scanner (Comair, Commonwealth Aircraft Corporation Limited, Australia) after the removal of plant debris. Oven-dried $\left(60^{\circ} \mathrm{C}\right)$ weights of ronts were recorded.

The shoots of plants selected for the soil-root monolith sampling were cut at the soil surface and separated into leaves, stems and pods. Leaf area was measured using a leaf area meter (LI-COR Model 3100 Area Meter). The separated plant parts were oven-dried $\left(60^{\circ} \mathrm{C}\right)$ for three days and the dry weights recorded.

The static parameters of the plants, which the model requires as initial inputs, were either measured or taken from available literature (Jones el al., 1991) and are listed in Table 1.

The soil, a medium deep Alfisol (Ferric Luvisols; Udic Rhodulstalf) is widespread throughout the semi-arid tropics. It has a low water-holding capacity and is characterized by a lack of soil aggrcgation in the surface and by the presence of murrum (hard pan layers) in the sub-soil. Detailed physical and chemical characteristics of this soil have been described by El-Swaify et al. (1985).

To collect input data for the model, the physical and chemical properties of the soil samples from various depths were analysed by procedures described in Page et al. (1982). The data obtained were used to create the soil profile data (Table 2) required for input to the model, using the soil data retrieval facility in Decision Support System for Agrotechnology Transfer (DSSAT Ver. 2.1, 1987) software developed by International Benchmark Soils Network for Agrotechnology Transfer (IBSNAT). Soil moisture content was computed using data collected weekly by the gravimetrical method for the top two layers and with a neutron probe (Depth Moisture Gauge, Model 3332, Troxler Electronic Laboratories Inc., NC, USA) for the deeper layers.

\section{The model}

Jones et al. (1991) have described a root model that simulates the root growth of maize as affected by major soil properties, weather and crop characteristics. This model was used in this study of pigeonpea as the authors had suggested that it was 
Tablc I. Input data for the model; parameters of the plant

\begin{tabular}{|c|c|c|}
\hline Description & Input & Remark \\
\hline Normal maximum root system depth $(\mathrm{m})$ & 2.5 & Default value $\dagger$ \\
\hline $\begin{array}{l}\text { Growth stage when root depth reaches maximum (unity being } \\
\text { physiological maturity; Jones et al., 1991) }\end{array}$ & 0.4 & 0-1 Observed data \\
\hline $\begin{array}{l}\text { Normal ratio of root length to root weight in plough layer at } \\
\text { maturity }\left(\mathrm{mg} \mathrm{g}^{-1}\right)\end{array}$ & 8.0 & Observed data \\
\hline Normal ratio of root length to weight in seedling $\left(\mathrm{m} \mathrm{g}^{-1}\right)$ & 40.0 & Observed data \\
\hline $\begin{array}{l}\text { Root weighting coefficient-geotropism-(rooting characteristic; } \\
\text { Jones et al., 1991; Robertson el al., 1993) }\end{array}$ & 1.0 & Derived parameter \\
\hline Base temperature for root growth $\left({ }^{\circ} \mathrm{C}_{\mathrm{i}}\right)$ & 8.0 & Default value \\
\hline Optimum temperature for root growth $\left({ }^{\circ} \mathrm{C}\right.$ ) & 25.0 & Default value \\
\hline Calcium saturation below which root growth is reduced (\%) & 15.0 & Default valuc \\
\hline Calcium saturation below which root growth is negligible (\%) & 0.0 & Default value: \\
\hline Aluminium saturation below which root growth is unaffected $(\%)$ & 13.0 & Default value \\
\hline Aluminium saturation above which root growth is negligible (\%) & 90.0 & Default value \\
\hline Planting depth (mı) & 0.05 & Observed value \\
\hline $\begin{array}{l}\text { Growth stage when normal root senescence begins (unity being } \\
\text { stage at which root attains physiological maturity; Jones } e l \\
\text { al., 1991) }\end{array}$ & 0.8 & 0-1 Observed valu \\
\hline $\begin{array}{l}\text { Fraction of normal root growth when pore space is saturated } \\
(0-1)\end{array}$ & 0.0 & Default valuc \\
\hline
\end{tabular}

†Default value is that suggested by the authors of the model (Jones et al., 1991).

Table 2. Input data.for the model; physico-chemical properties of the soil profile

\begin{tabular}{lccccccc}
\hline $\begin{array}{l}\text { Soil } \\
\text { laycr } \\
(\mathrm{cm})\end{array}$ & $\begin{array}{c}\text { Bulk } \\
\text { density } \\
\left(\mathrm{g} \mathrm{cm}^{-3}\right)\end{array}$ & $\begin{array}{c}\text { Sand } \\
(\%)\end{array}$ & $\begin{array}{c}\text { Silt } \\
(\%)\end{array}$ & $\begin{array}{c}\text { Coarsc } \\
\text { fragments } \\
(\% \text { vol. })\end{array}$ & $\begin{array}{c}\text { Sum of } \\
\text { bases } \\
\left(\mathrm{cmol} \mathrm{kg}^{-1}\right)\end{array}$ & $\begin{array}{c}\text { Extractable } \\
\mathrm{Al} \\
\left(\mathrm{cmol} \mathrm{kg}^{-1}\right)\end{array}$ & $\begin{array}{c}\text { Fixchangeable } \\
\mathbf{C a} \\
\left(\mathrm{cmol} \mathrm{kg}^{-1}\right)\end{array}$ \\
\hline $0-10$ & 1.58 & 66.7 & 9.8 & 0.06 & 4.4 & 0.15 & 2.71 \\
$10-22$ & 1.60 & 62.5 & 10.6 & 0.06 & 4.2 & 0.14 & 2.82 \\
$22-30$ & 1.60 & 58.3 & 11.3 & 0.06 & 5.9 & 0.14 & 4.22 \\
$30-45$ & 1.60 & 52.2 & 13.8 & 0.09 & 7.5 & 0.14 & 5.16 \\
$45-60$ & 1.60 & 52.2 & 13.8 & 0.10 & 7.5 & 0.14 & 5.31 \\
$60-75$ & 1.59 & 52.2 & 13.8 & 0.20 & 7.0 & 0.13 & 4.92 \\
$75-90$ & 1.59 & 52.2 & 13.8 & 0.20 & 7.7 & 0.13 & 5.39 \\
\hline
\end{tabular}

sufficiently flexible to allow simulation of root growth for a variety of soils, climate and plant species.

In the model, effects of static and dynamic factors on root growth are expressed as stress factors, which range from 0 (no growth) to 1.0 (no stress), the property with the most unfavourable stress factor being considered to limit the root growth. Length/weight ratios of the roots in the model are calculated as a function of the crop growth stage and the average depth of the soil layer relative to root system depth. The final outputs from the model are given on a daily basis for depth of the rooting front, length and weight of roots in each soil layer, and loss of roots by senescence. 


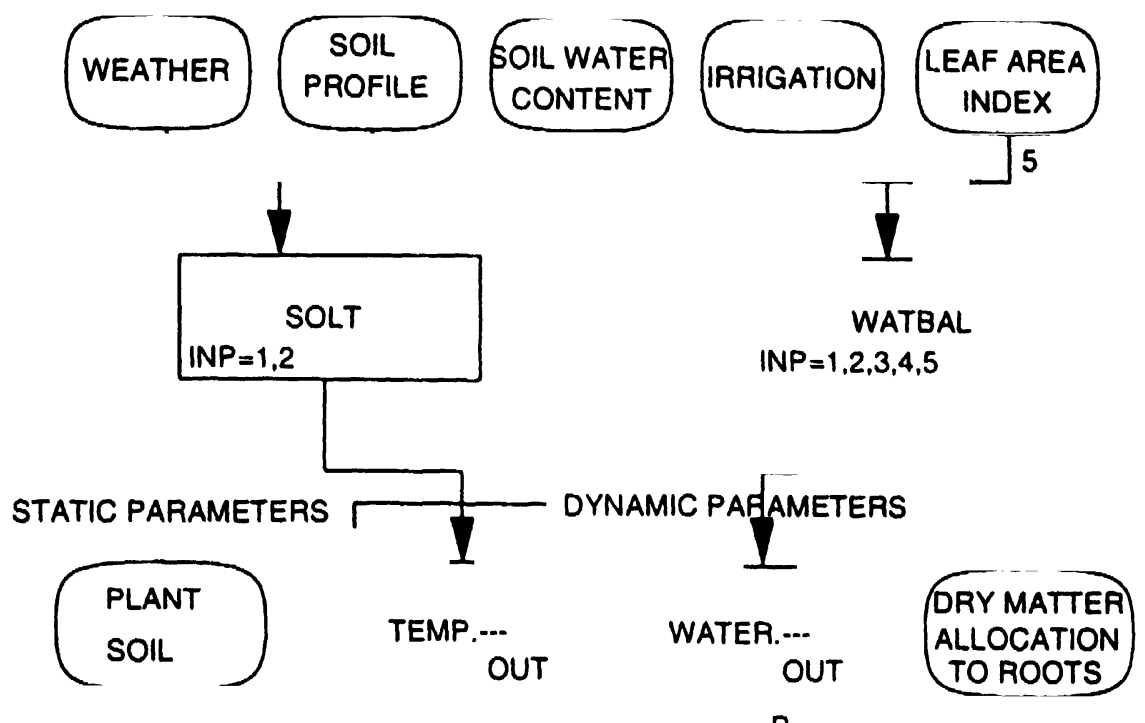

B

ROOT
INP $=6,7, A$
Daily
Rooting profile
Rooting front
Root weight
Senescence

Fig. 2. Flow diagram of the modelling exercise for root simulation.

The entire modelling exercise consisted of two stages, as shown in the flow diagram (Fig. 2). The first stage involved estimation of soil moisture content and mean soil temperature at the centre of each layer, using dynamic variables which directly affected root growth. The volumetric water content was simulated using Ritchie's multi-layered water balance sub-routine W $\Lambda \mathrm{TB} \Lambda \mathrm{L}$ and temperature was simulated with the sub-routine SOI.T, both from the CERES-Maize model (Jones and Kiniry, 1986). The inputs for these simulations used weather data (maximum and minimum temperature and rainfall), the soil characteristics of each layer, water amendment by irrigation, initial water content in the soil profile, and leaf area index at various growth stages.

The second stage of the operation of the root model used these data sets combined with certain static parameters for the plants (Table 1), the soil profile characteristics (Table 2), and daily dry matter allocation to roots. Since a growth model has not been established for pigeonpea, and data on daily dry matter accumulation in shoots and roots were not available, an attempt was made to 
derive a model from the measured data. A growth curve for shoots and roots was fitted to a logistic function with time (Thornley and Johnson, 1990) and daily dry matter allocation to roots computed from the daily increases in the root weight using the equation obtained by the logistic simulation. Root length densities and root weights simulated by the root model were compared with the observed data.

\section{RESULTS}

\section{Soil characteristics}

Soil $\mathrm{pH}\left(\mathrm{H}_{2} \mathrm{O}\right)$ decreased from 6.5 to 5.5 and electrical conductivity increased from 0.15 to 0.3 as depth increased from 0 to $90 \mathrm{~cm}$. The phosphorus (troug-P) level decreased from 89 to $4 \mathrm{ppm}$ with depth and the potassium level from 4.5 to $0.49 \mathrm{ppm}$. Ammonium nitrogen increased with depth from 6.1 to $11.4 \mathrm{ppm}$, but no clear trend was observed for nitrate-nitrogen, which ranged from 3.4 to $7.8 \mathrm{ppm}$.

The simulated volumetric water content at the centres of five different soil layers was compared with the observed values (Fig. 3). The simulated volumetric water content clearly reflected the rainfall and irrigation in all layers of the soil profile. Regressions between simulated and observed values of volumetric water content and soil temperatures were only significant in the top two layers but the observed values in Fig. 3 were obtained at approximately weekly intervals while the simulated values were calculated on a daily basis.

\section{Growth analysis}

The leaf area index reached a maximum 60 days after sowing (DAS), decreasing to 1.79 by 108 DAS (Fig. 4a). Dry matter accumulation in the roots was satisfactorily fitted to a logistic function (Fig. $4 \mathrm{~b}$ ) with $\mathrm{R}^{2}$ of 0.95 . Daily dry matter translocation to the roots was computed (Fig. 4c) and was slow initially, increasing towards the flowering stage and reaching a maximum $70 \mathrm{DAS}$. The root/shoot ratio was reasonably constant with values ranging between 0.17 and 0.19 throughout the growth period, indicating that the dry matter allocation to the roots could be easily calculated from the root/shoot ratio on a daily basis if shoot weights were provided by a growth model.

\section{Root model output}

When the simulated values for root length (Fig. 5) and weight in the different soil layers were compared with the observed values, the regressions were significant (Table 3) though the level of significance was less for deeper layers. Most of the observed data points lay in the $95 \%$ confidence bands of the fitted line. The correlation was far from a 1:1 relationship, especially for most of the root length densities and root weights at the surface. Pigeonpea develops rigid subsidiary roots, since it has the tap root system typical of leguminous plants, and these roots hold most of the dry matter located below-ground. Although root 


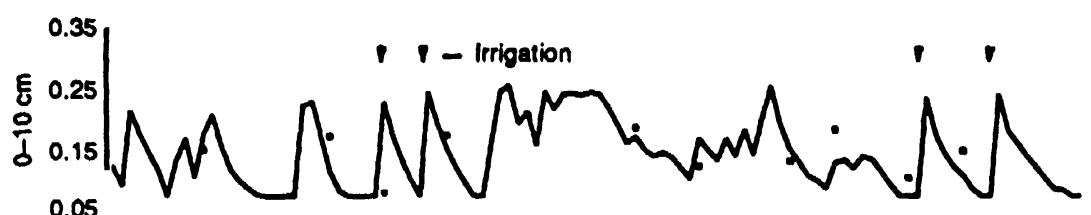

$8: .85$
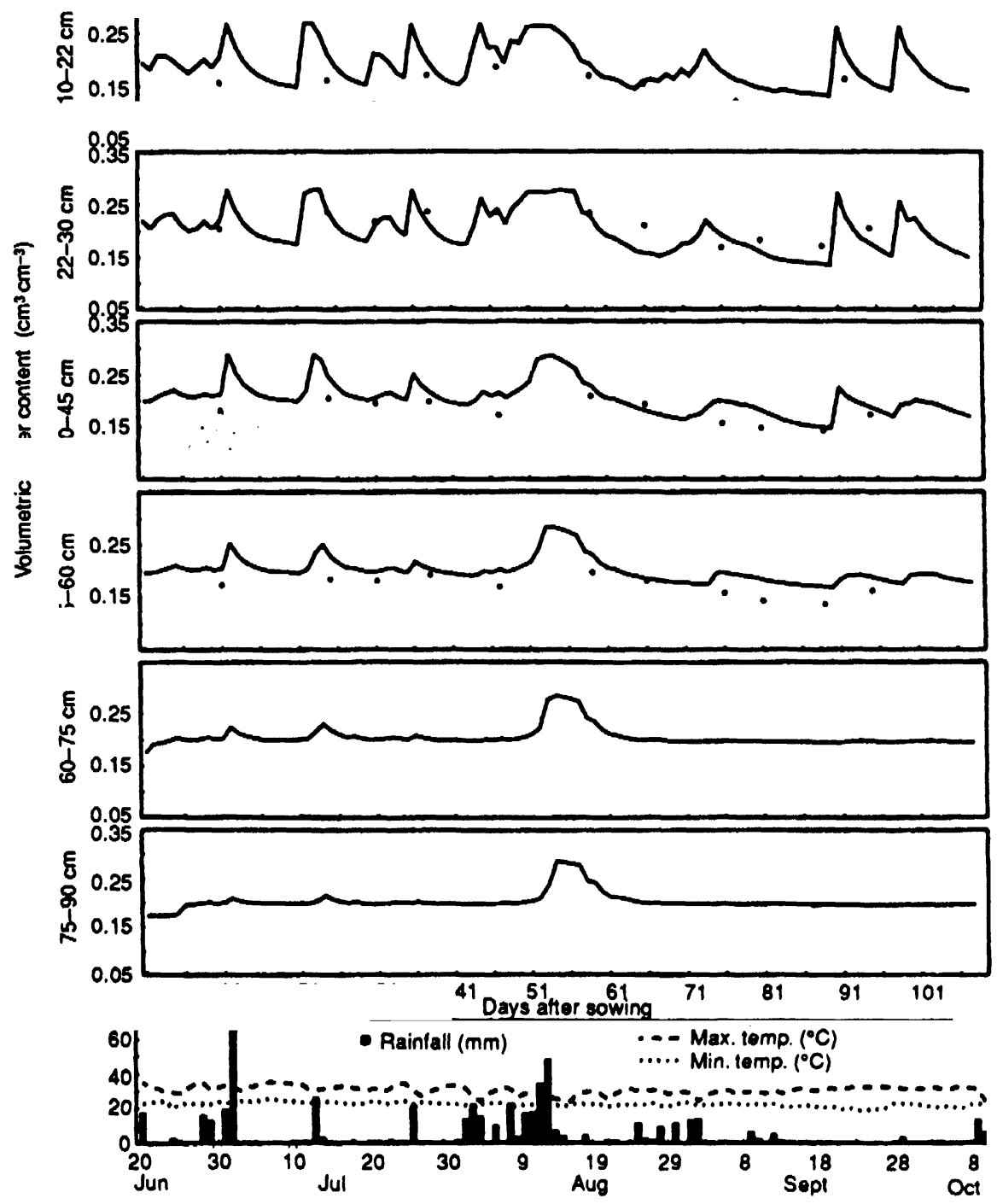

Fig. 3. Volumetric water content (observed and simulated _-) at different depths in the soil profile during the growth period of pigeonpea. Observed data not available for $6(0)-7.5$ and $75-90 \mathrm{~cm}$ depths.

Rainfall, maximum and minimum temperatures are presented at the bottom.

growth was observed in terms of length in the deeper soil layers from an early growth stage (Fig. 5), this made a negligible contribution to the total root weight. Changes in root lengths and weights down the soil profile could not be simulated by the model for pigeonpea, although they can be simulated for the maize crop for which the model was originally used. Maize has a fine root system even in the 

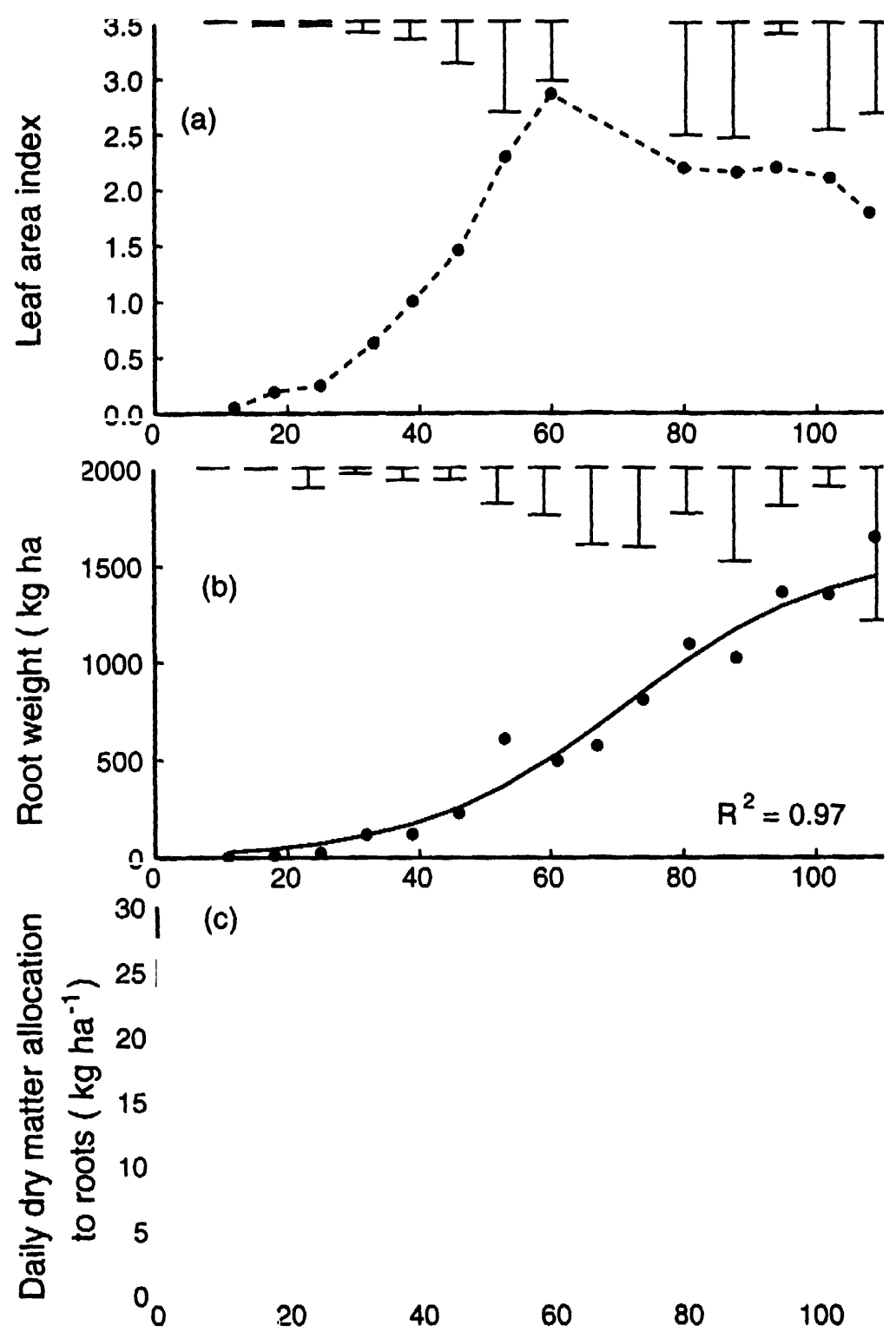

(c)

Days after sowing

Fig. 4. Leaf area index (a), dry matter accumulation in the roots, observed and — simulated using a logistic equation, (b), and daily allocation of dry matter to the roots (c) in pigconpea. Vertical bars indicate standard errors.

surface layer. The simulation for pigeonpea was carried out to give the best fit to the observed root length, so root weight was underestimated, especially at the surface. To give a better fit to the observed data, it would be desirable to formulate the changing pattern of length/weight ratio with soil depth and incorporate it into the model. 

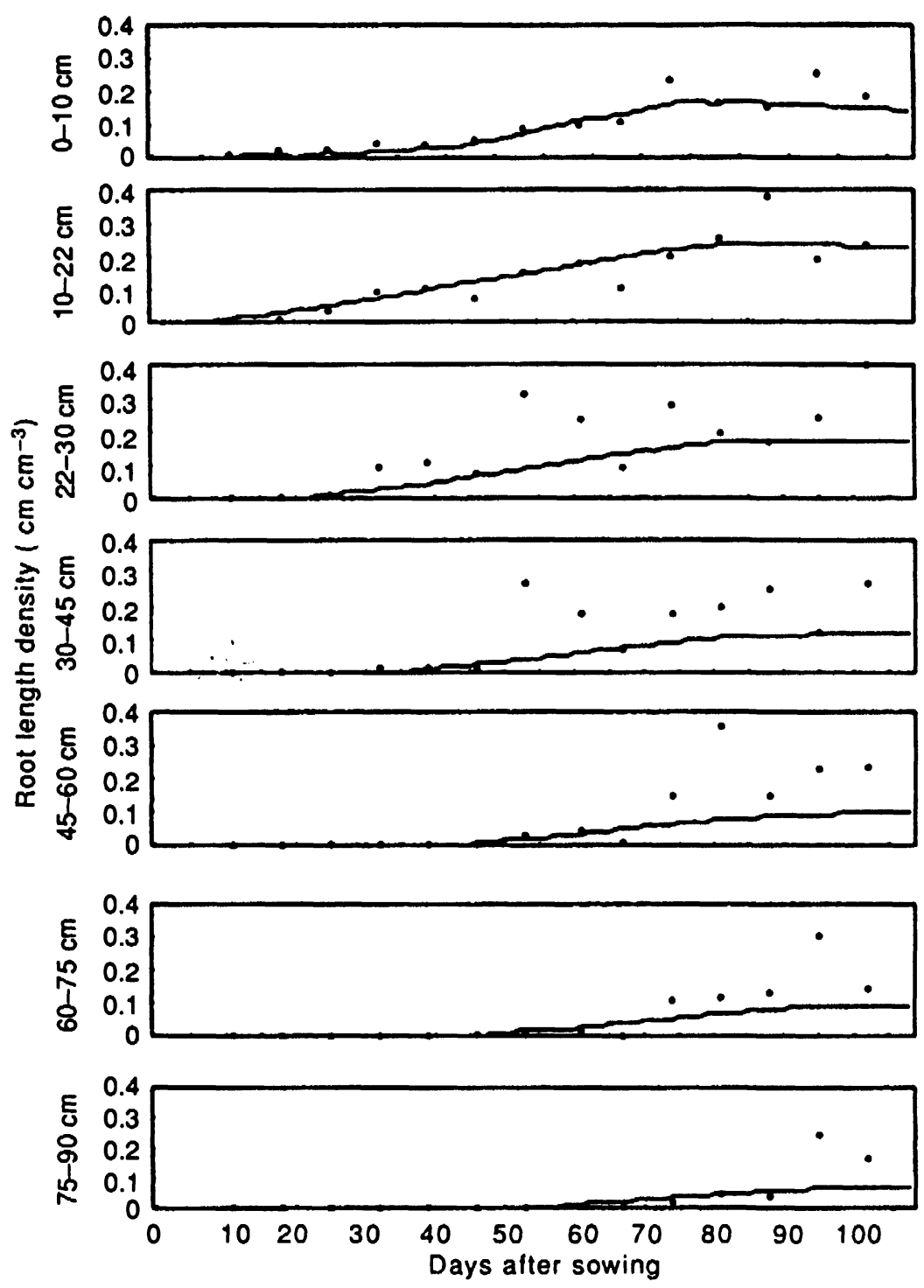

Fig. 5. Root length densities (observed and simulated _-) at diflerent deptliss in tlee soil profile.

\section{DIScussion}

Although the static stress factors did not greatly restrict root growth, the model was very sensitive to minor variations in soil bulk density. This in turn decreased the importance of the soil strength stress factor and this limits root growth simulation. Hence, the accuracy of bulk density measurements is of prime importance.

The model simulated root distribution with depth well but predictions of the accumulated root length were less reliable. The value of the root weighting coefficient (WCG) (Table 1), was altered from a default value of 3 (Jones $e t$ al., 
Table 3. Regression coefficient $\left(R^{2}\right)$ and slope (b) for linear relation between observed and simulated data for root length density and root weight

\begin{tabular}{rlrlll}
\hline \multirow{2}{*}{$\begin{array}{l}\text { Soil } \\
\text { layer } \\
(\mathrm{cm})\end{array}$} & \multicolumn{2}{c}{ Root length density } & & \multicolumn{2}{c}{ Root weight } \\
\cline { 2 - 3 } \cline { 5 - 6 } & $\mathrm{R}^{2}$ & $\mathrm{~b}$ & & $\mathrm{R}^{2}$ & $\mathrm{~b}$ \\
\hline Total & $0.88^{* *}$ & 0.63 & & $0.95^{* *}$ & 0.67 \\
$0-10$ & $0.86^{* *}$ & 0.75 & & $0.92^{* *}$ & 0.19 \\
$10-22$ & $0.76^{* *}$ & 0.70 & & $0.88^{* *}$ & 0.69 \\
$22-30$ & $0.58^{*}$ & 0.42 & & $0.71^{* *}$ & 1.33 \\
$30-45$ & $0.59^{*}$ & 0.35 & & $0.73^{* *}$ & 1.35 \\
$45-60$ & $0.75^{* *}$ & 0.29 & & $0.82^{* *}$ & 1.16 \\
$60-75$ & $0.75^{* *}$ & 0.35 & & $0.76^{* *}$ & 1.18 \\
$75-90$ & $0.65^{*}$ & 0.31 & & $0.68^{* *}$ & 0.88 \\
\hline
\end{tabular}

",** denote significance at $p<0.05$ and $p<0.01$, respectively.

1991) to a calculated value of 1 to simulate a root distribution that was less skewed towards the surfacc than in maize (Fig. 5). This weighting coefficient was calculated from the relation WCG $=\mathrm{RTDEP} \times k$ (Robertson et al., 1993), where WCG is the root weighting coefficient, RTDEP the maximum rooting depth, and $k$ the decay constant. The decay constant is obtained from the relation $\rho=\rho_{0} \operatorname{Exp}$ $(-k z)$ (Ito et al., 1992) where $\rho$ is the root length density $\left(\mathrm{cm} \mathrm{cm}^{-3}\right), \rho_{0}$ and $k$ arc coefficients characteristic of the plant and environment, and $\mathrm{z}$ is the depth $(\mathrm{cm})$.

Assuming that the profile distribution of roots along the soil layers is exponential with soil depth, the values for $k\left(\mathrm{~cm}^{-1}\right)$ and $\rho_{0}\left(\mathrm{~cm} \mathrm{~cm}^{-3}\right)$ are closely related to rooting depth and the intensity of root proliferation in the surface layer of soil, respectively (Ito et al., 1992). The values of $k$ and $\rho_{0}$ were computed using observed root length densities and plotted against growth duration (Fig. 6) which showed a close correlation between $k$ and $\rho_{0}$. The regression coefficient became significant (0.73) after excluding the initial two data points, where the number of data sets was insufficient for reliable fitting with an exponential equation. The positive correlation between $k$ and $\rho_{0}$ implies that the plant which develops fewer roots at the surface may attain a deeper rooting depth.

The steady decline in $\rho_{0}$ after 50 DAS indicates that less dry matter would be allocated to the surface layers and more to the middle and lower layers. This is reflected in Fig. 5, which shows that pigeonpea tended to develop more root length in the middle and lower layers than in the surface layer as growth proceeded. The maximum rooting depth, a major input to the model, was attained at about 53 DAS, after which more root was observed in the middle layers than near the surface.

The model needs to be tested to consider the allocation of dry matter to roots at the various layers in the soil profile if adequate simulation of the pigeonpea root system is to be achieved. This is because it has a tap root system with considerable branching and the tap root contributes to the root weight in the surface layer of the 


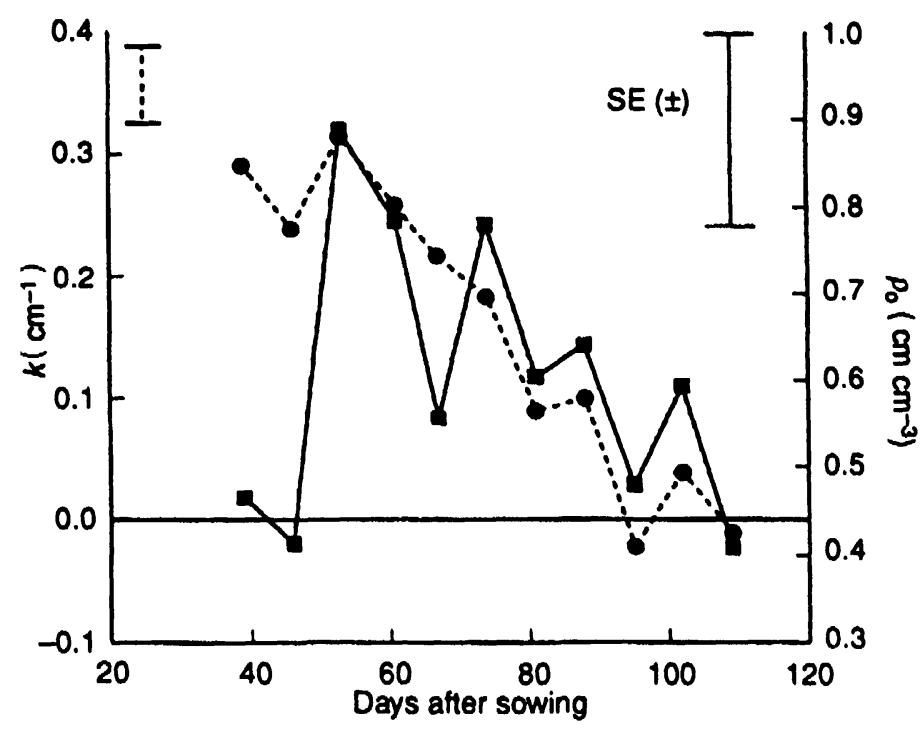

Fig. 6. Coefficients $k$ (-) and $\rho_{0}(\square-a)$ obtained by an exponential simulation for profile distribution of root length density $\left[\rho=\rho_{11} \operatorname{Exp}(-k \%)\right.$, where $\rho$ is root length density and $\%$ soil depth).

soil while the lateral roots contribute mainly to root length, but very little to root weight because of their thin fine structure. This could be the reason for the underestimation of root weights in the top layer and of root length densities in the middle to lower layers. Rivera et al. (1983) reported that a large proportion of roots of pigeonpea was confined within a $45-60 \mathrm{~cm}$ soil depth zone. Hence the roots of pigeonpea are distributed in the middle layers, whereas cereals have a root distribution which is positively skewed to the surface layers.

The length/weight ratios of roots need to be monitored closely by making frequent and accurate measurements since they are highly variable within layers, and thus contribute to the partitioning of dry matter to the various soil layers. Root length of pigeonpea increased down the profile whereas root weight decreased.

Partitioning of root length within the soil profile is largely affected by soil water content. Robertson et al. (1993) proposed that the root weighting coefficient should be related with a function of the surface soil water content, because Blum and Ritchie (1984) had shown that penetration of adventitious roots at the soil surface was inhibited if the soil water content fell below $70 \%$ of the extractable water content. Merrill and Rawlins (1979) have also shown that the soil moisture content in the surface layers determines the concentration of root mass and subsequent growth response of existing roots. This feature may have to be built into the model for the proper partitioning of root length in the profile. The simulation of the pigeonpea root system may be greatly improved if provision is made in the model for the deep rooting characteristics and capacity to penetrate the murrum layer in the Alfisol (Arihara et al., 1991). This would involve progressive changes to the root length/weight ratio for each soil layer. 


\section{REFERENCES}

Adams, F. \& Moore, B. L. (1983). Chemical factors affecting reot growith in sulsovil horizons of coastal plains suils. Soil Science Sociely of America Journal 47:99-102.

Arihara, J., Ae, N. \& Okada, K. (1991). Root development of pigeonpea and chickpea and its signiticance in different cropping systems. In Phosphorous. Nulrition of (irain legumes in the Semi-Arid Tropics, 18.3-19.1 (F.ds C. Johansen, K. K. Lee and K. L. Salhrawat). Pattancheru, India: International ('rops Rescarch Institute for the Semi-Arid Tropics (IC:RISAT).

Asady, G. H. \& Smucker, A.J. M. (1989). Compaction and root moditications of soil aeration. Soil Sicience Societ? of America Journal 53:251-254.

Blum, A. \& Ritchic, J. T. (1984). Effect of soil surface water content on sorghum roset distribution in the soil. Field Crops Research 8:169-176.

Drew, M. (. (1983). Plant injury and adaptation to oxygen deficiency in the root conviromment: A review. Plant and Soil 75:179-199.

DSSAT, Ver 2.1. (1987). Decision support sỵstem for agrotechnology transfer. In DSSSAT I iseris (ituide. Hawaii, Honolulu: International Benchmark Soils Network for Agrotechnology Transter (IBSNA'I), University of Hawaii. Honolulu, HI, 96822?.

El-Swaily, S. A., Pathak, P., Kego T. J. \& Singh S. (1985). Soil management lor optimized productivity under rainfed conditions in the semi-arid tropics. Advances in Soil Science 1:1 6.1.

Gerard, C. J., Sexton, P. \& Shaw. (i. (1982). Physical factors influcncing soil strength and root growill. Agronomy Journal 74:875-879.

Gregory, P. J. (1986). Response tor temperature in a stand of pearl millet (P'enmiselum !yphoides S. and H.). Journal of Experimental Boluny 37: 379-388.

Hecraman, 1). A. \& Juma, N. G. (1993). A conparison of minirhizotron, core and monolith medhods for quantifying barley (Ilordeum mulgare $\mathrm{I}_{\text {.) }}$ and faba bean (licia fabal $\mathbf{l}$.) root distribution. Plant and Soil 148:29-41.

Hoogenboom, G. \& Huck, M. (3. (1986). ROOTSIML' H4.0-A D.jnamic Simulation of Root (irnuth, Hater Uptake, and Biomass P'artitioning in a Soil-P'lant-Almosphere Continuum: (Ipdate and Documentation. Alabama Agricultural Experimental Station Agronomy and Soils Departmental Series No. 109.

Huck, M. G. \& Hillel (1983). A model of root growth and water uptake accounting for photosynthesis, respiration, transpiration, and soil hydraulics. In Advances in Irrigation, Vol. 2, 273-3333 (Fd. I). Hillcl). New York: Academic Press.

Ito, ()., Matsunaga, R., Tobita, S. \& Rao, 'T. P. (1992). Rooting behavior of intercropped pigeonpea (Cajanus cajan (I.) Millspaugh) and sorghum (Sorghum bicolor (I.) Mocnch). In Root Eicology' and its P'ractical Application, 412-422 (Eds I. Kutchera, E. Hubl, E. Lichtenegger, H. Persson and M. Sobotic). Bodenkultur: Wien University.

Jones, C. A., Bland, W. I.., Kitchice,J. T. \& Williams, J. R. (1991). Simulation of root growth. In Modeling I'lant and Soil Systems, 91-123 (Eds R. J. Hanks and.J. 'I'. Ritchic). American Society of Agronony, Inc., Crop Science Socicty of America, Inc. and Soil Science Society of $\Lambda$ merica, Inc.

Jones, C. A. \& Kiniry, J. R. (1986). CERESS-Maize: A Simulation Model of Maize Growth and Denelopment. College Station, Texas: T'exas A\&M University Press.

Merrill, S. D. \& Rawlins, S. I.. (1979). Distribution and growth of sorghum roots in response to irrigation frequency. Agronomy Journal 71:735-745.

Page, A. L., Miller, R. H. \& Keeney, D. R. (1982). Methods of Soil Analysis Part 2. Madison, Wisconsin, USA: Amcrican Society of Agronomy.

Ritchey, K. D., Silva, J. F. \& Costa, U. F. (1982). Calcium deficiency in claycy B horizons of savanna Oxisols. Soil Science 133:378-382.

Rivera, E., Silva, S. \& Vicente-Chandler, J. (1983). Distribution of pigeonpeas, cassava, coffec and grass roots in Ultisol. Journal of Agriculture University of Puerto Rico (67):278-285.

Robertson, M. J., Fukai, S., Hammer, G. L. \& Ludlow, M. M. (1993). Modelling roxt growth of grain sorghum using the CERES approach. Field Crops Research 33:113-130.

Thornley, J. H. M. \& Johnson, I. R. (1990). Plant and Crop Modelling. A Mathematical Approach to Plant and Crop Physiology, 74-89. New York: Oxford University Press. 